\title{
Technológiai megfigyelések a rákóczifalvi temetö bifaciális levélhegyén
}

\author{
Faragó Norbert \\ ELTE BTK Régészettudományi Intézet, Budapest \\ E-mail:faragonorber@caesar.elte.hu
}

Kivonat. Jelen tanulmány tárgyául Rákóczifalva-Bivaly tó $1 / \mathrm{C}$ lelőhely 218/230-as szimbolikus sírjának bifaciális kidolgozású levélhegye került kiválasztásra. A tárgy megnevezése használati nyom elemzés hiányában szándékosan nem nyílhegy, lándzsahegy vagy tőr, mivel ezek a terminusok mind egyúttal valamilyen funkcióbeli sajátosságra is utalnak. A lelet és lelőhelykörülmények, a lehetséges párhuzamok ismertetésén túl a tárgy technológiai elemzése került előtérbe, a készítés során megvalósult, egymást követő lépések és fogások megfigyelése és rögzítése történt meg. Az elemzés célja közvetlen módon felfedni a levélhegy készítésének körülményeit, a készítés helyét és a készítő(k) szakértelmének szintjét, közvetett módon pedig adalékot szolgáltatni a rézkorban tapasztalható technológiai újítás megjelenéséhez és a kapcsolatrendszerek kibővüléséhez. Az eredmények alapján a helyi készítés szinte teljesen kizárható, ugyanakkor a levélhegy nyersanyaga, magas szintű kivitelezése és a leletkontextusban megnyilvánuló szokás általános képe mind nagyon erős kapcsolatokat valószínűsít az észak-bulgáriai régióval.

Kulcsszavak: bifaciális levélhegy, balkáni kova, rézkor, Bodrogkeresztúri kultúra

Hivatkozás: Faragó, N. (2021). Technológiai megfigyelések a rákóczifalvi temető bifaciális levélhegyén (Technological observations of a bifacial leaf point from the cemetery of Rákóczifalva). In N. Faragó, A. Király, \& K. I. Szegedi (szerk.), A tealevelektől a levélhegyekig. Tanulmányok Mester Zsolt tiszteletére 60. születésnapja alkalmából (pp. 77-94). Litikum \& ELTE BTK Régészettudományi Intézet.

https://doi.org/10.23898/litikumsi01a04

000 hitikum könyvtár 1 
Jelen tanulmánnyal szeretném köszönteni a 60 éves Mester Zsoltot, akit nem csak tanáromnak, témavezetőmnek, mentoromnak, hanem barátomnak is van szerencsém tartani. Ezúton is köszönöm az elmúlt évek megannyi útmutatását, tanácsát, amelyek mentén elmélyülhettem a kőeszközök tanulmányozásában! Kívánom, hogy még legalább ennyi éven át folytathassuk azokat a ránk jellemző hosszú és alapos diskurzusainkat, amelyeknek a végén mindig rájöttünk, hogy tulajdonképpen ugyanarról beszélünk, csak más szemszögből!

Isten éltessen Zsolt!

\section{Bevezetés}

Köeszközök a magyarországi neolitikus és rézkori sírokban

A késő neolitikum végén alapvető változások történtek az addigi gazdasági, társadalmi és kulturális jellemzők tekintetében. A tellek felhagyásával és a nagy kiterjedésű, soros temetők megjelenésével a pattintott kőanyagban is jelentős új vonásokat lehetett megfigyelni (Kaczanowska, 1985; T. Biró, 1998). Ezeknek a rézkorban általánossá váló jelenségeknek egy része ugyanakkor nyomokban felbukkant már a neolitikum korábbi időszakaiban a Kárpát-medencében. Az első ilyen jelenség a pattintott kövek sírokban, mellékletként való elhelyezése, különös tekintettel az ép pengékre, pengetöredékekre. Noha a rézkor idején gyakoribbá váló temetők alapján természetesnek tűnik, hogy a tárgyi kultúra előkerülési helye is nagyobb valószínűséggel köthető sírokhoz, a pattintott kövek tekintetében ez mégsem magától értetődő kulturális elem. Mégis, az Alföldön már a középső neolitikum időszakában lehet számolni ezzel a szokással, ráadásul eléggé markáns, konzekvens formában (Whittle et al., 2013, 75. o.; Oravecz, 1996; Faragó et al., 2016). A Dunántúl területén ezzel párhuzamosan, a Vonaldíszes időszakban hasonló trend bontakozott ki (Oross
\& Marton, 2012; Fábián et al., 2007). A következő, Lengyeli kultúra időszakában a Dunától nyugatra hangsúlyos elemmé vált a nagy sírszámú temetők használata, ezzel együtt a pattintott kő mellékletadási szokás is egyre gyakoribbá vált (Bácskay, 1989, 1990; Zalai-Gaál, 2010, 114-122. o.). Az Alföld területéről származó pattintott kő sírmellékletek jellemzőiről egyelőre még keveset tudunk, a legtöbb esetben csak az ilyen tárgy előfordulásáról vagy hiányáról, esetleg nyersanyagáról tájékozódhatunk a szakirodalomból (Siklósi, 2013). Kivételt jelent Polgár-Csőszhalom, ahol a külső telep 20 sírja alapján sikerült kimutatni, hogy a pattintott kő melléklet hangsúlyosan a fiatal-középkorú férfiak (30-40 év) attribútuma, és jellemzően trapézokat, csonkított vagy sima pengetöredékeket és ép pengéket helyeztek melléjük (Faragó, 2017, 2019).

\section{A volhiniai/pruti kova}

A második jelenség, ami a magyarországi rézkori kőegyüttesek sajátja, egy specifikus nyersanyag, az ún. volhíniai/pruti kova széles körben való előfordulása. A két elnevezés között szükséges lenne különbséget tenni, hiszen hiába származik mindkét nyersanyag hasonló, kréta kori környezetből, földrajzilag némileg eltérő területen fordulnak elö, és a keletkezésükben is vannak eltérések (Rhyzov et al., 2005, Fig. 3; Crandell \& Vornicu, 2015, Fig. 1-2). Makroszkopikusan mindkettő nagyon hasonló, a sötétszürkétől a fehéresig terjedhet a színük, lehetnek áttetszők, homogének, vagy akár sávos mintázatúak, viszont egységesen finom szerkezetűek, a kérgük a kréta kori mészkőnek megfelelően pedig fehér színű. Mivel magyarországi leleteken még nem történt kísérlet a két nyersanyag forrásának elkülönítésére, így a továbbiakban is érdemes volhíniai/pruti kovaként hivatkozni rá. Ez a nyersanyag ugyan már a paleolitikumban megtalálható itthoni leletanyagokban (T. Dobosi \& Varga, 1991; Kozłowski et al., 2009, 418. o.; Mester \& Kozłowski, 2014, 
356. o.), a mi szempontunkból viszont a középső neolitikumra datálható adatok a fontosak. Ilyenre példa Gerla-Kászmán, Felsővadász-Várdomb, Ináncs-Dombrét, Szécsény-Ültetés (T. Biró, 1998, 39., 44., 45. o.), illetve Borsod-Edelény (Kaczanowska, 1985, 59. o.). A késő neolitikum kutatásában a volhíniai/pruti kova neve ma már összeforrt Berettyóújfalu-Herpály lelőhelyével, és a vele fémjelzett kultúrával (Kaczanowska, 1985; T. Biró, 1998; Raczky et al., 2020). Ez is jelzi a Kárpátokon túli kapcsolatok intenzívebbé válását, ezen a lelőhelyen ugyanis a pattintott kőegyüttes több mint felét ez a nyersanyag alkotja. Az Alföld egyéb késő neolitikus lelőhelyein, mint Polgár-Csőszhalmon, Polgár-Bosnyákdombon, Öcsödön vagy Gorzsán ez az intenzivitás még csak hasonló mértékben sem fordul elő, mégis megszokott komponense ezeknek az együtteseknek (Kaczanowska et al., 2009; Kaczanowska \& Kozłowski, 2015; Starnini et al., 2007, 2015; Faragó 2017, 2019). A kora rézkortól kezdve ez a nyersanyag aztán elengedhetetlen kísérőjévé vált a férfi sírok együtteseinek (Bognár-Kutzián, 1963), noha a forrásterület hazai felismerése némiképp később történt csak meg (Kaczanowska, 1985).

\section{Bifaciális technológiával készült hegyek}

A harmadik hangsúlyos jellemző, amelyet a rézkori kőegyüttesekkel összekapcsolhatunk, az a bifaciális megmunkálású eszközök, illetve technológia felbukkanása. Ennek a tárgytípusnak és eszközkészítési hagyománynak nincs egyértelmű közvetlen helyi előzménye a Kárpát-medencében, paradox módon mégis újra feltalálásról beszélhetünk, hiszen a bifaciális kőeszközkészítés, párhuzamosan a kavicseszközökkel és a szilánkeszközökkel hosszú évezredekig jelen volt Európában és a szűkebb régiónkban is (Gábori, 1976, 157185. o., Fig. 54). Az utolsó eljegesedés maximuma idején még a hazánkban is jellemző levélhegyek fokozatosan eltűntek, és ez az eszköztípus illetve eszközkészítési metódus majdnem húszezer évig teljesen feledésbe merült (Lengyel \& Mester, 2008; Lengyel et al., 2015). Az epipaleolitikum és mezolitikum idején hegyként funkcionáló kőeszközök Nyugat- és Északnyugat-Európában igen változatos képet mutattak, de ezek nem bifaciális technológiával készültek (Rozoy, 1989). A geometrikus mikrolit hegyeket később a nyugat-európai Vonaldíszes kerámia kultúrájának időszakában is nyomon lehetett követni (Marton, 2011, 175. o.; Gronenborn, 1997). Számunkra azonban a bifaciális technológiával készült hegyek a fontosak, amelyek Kelet-Európában és a Balkánon úgy tünik, kétféle tradíció mentén bukkantak fel újra a késő neolitikumban (Marton, 2011, 169-175. o.). Ezek közül a rombusz alakú, nyelezett eszközök nagyrészt a Nyugat-Balkánon, illetve az Adria mentén és az Égeikumban terjedtek el, és főleg a Butmir időszakra keltezhetőek (Marton, 2011, 173. o.). Egy másik tradíció, melyhez a nyújtott, háromszög alakú hegyek és a nagyobb levél alakú hegyek köthetőek, a bulgáriai-romániai területeket kapcsolja össze az Észak-Pontus-vidékkel, vagyis a Kodžadermen-Gumelniţa-Karanovo VI komplexumot a Sălcuţa és a Pre-Cucuteni, Cucuteni-Tripolje körrel hozza szoros összefüggésbe (Marton, 2011, 169. o.; Boyadzhiev, 2015; Lichardus \& Lichardus-Itten, 1993). A két régió között térbeli és időbeli szempontból is Szerbia képezett határvidéket, ahol a késő neolitikumra keltezhető, és a Vinča kultúrával összefüggésbe hozható nyelezett, vállas darabok még az adriai területek hatásáról árulkodnak (Šarić, 2005, 14. o., Fig.2). A kora rézkor elején aztán megfordult ez a trend, és hasonló, nyelezés nélküli levél alakú hegyek kezdtek el megjelenni a szerbiai együttesekben.

\section{A technológiai vizsgálat alapjai}

A technológiai elemzés gyakorlatilag a készítés lépéseinek visszafejtését jelenti a tárgyon felismerhető jegyek alapján. A kőeszközök esetén abban a szerencsés helyzetben vagyunk, hogy az egyes lépések jeleket, úgynevezett stigmákat 


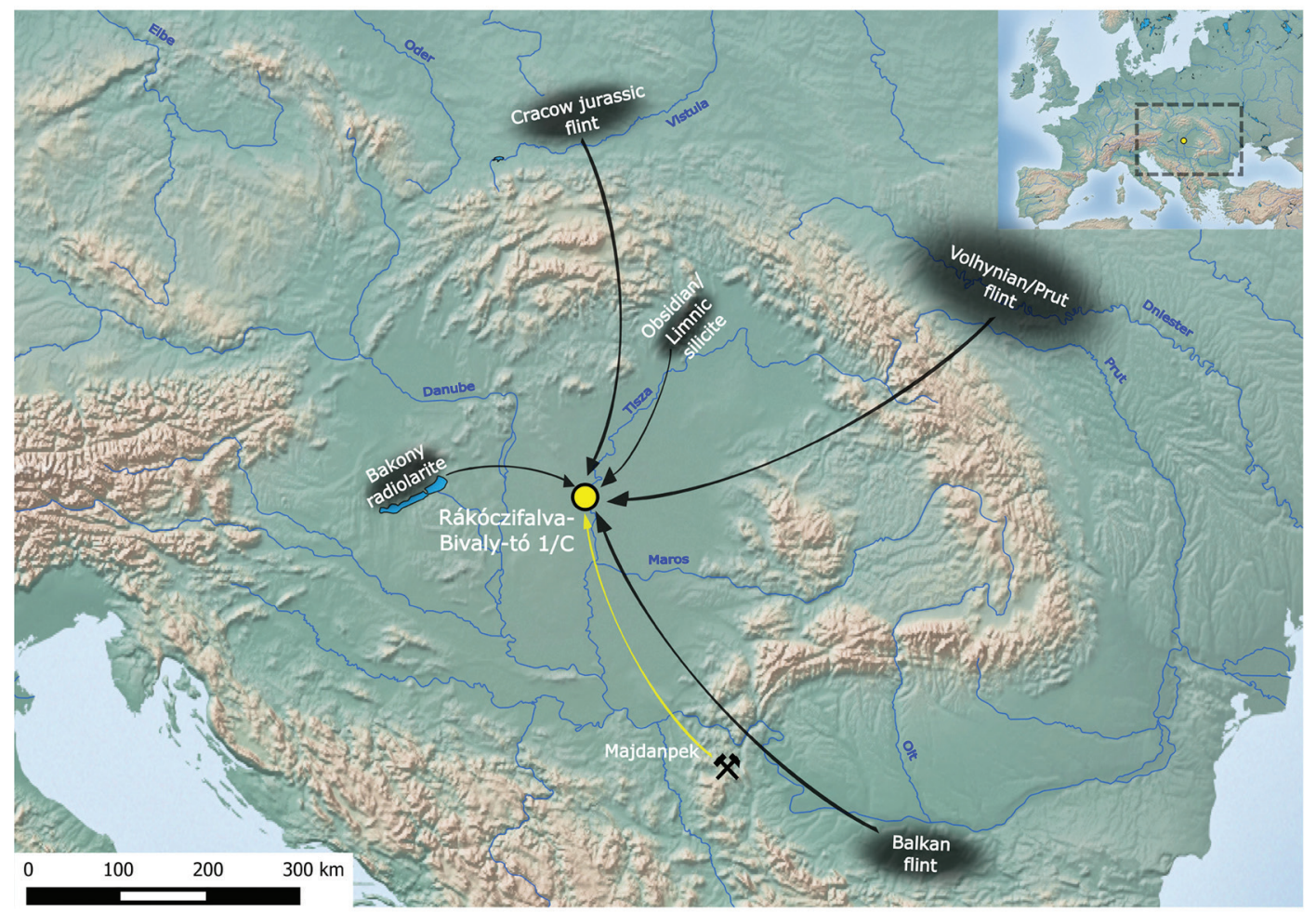

1. ábra. A Rákóczifalva-Bivaly-tó $1 / C$ lelőhely elhelyezkedése és kapcsolatrendszere a Kárpát-medencén kívüli régiókkal a pattintott kő és a réz tárgyak nyersanyagai alapján (Siklósi et al., in press, Fig. 1. nyomán).

hagynak maguk után, melyek a szakemberek számára olvashatók (Inizan et al., 1999; Holló et al., 2004). Ehhez a vizsgálathoz tehát nincs szükség az összes darab tényleges meglétére, elég csak a megmaradt leválasztásokat, negatívokat tanulmányozni. A rekonstrukciót ami előáll a kutató elméjében, mentális újraillesztésnek, remontázsnak hívjuk. Ami még fontosabb, egy ilyen vizsgálat során nem csak mechanikusan felfedjük, és rögzítjük a készítés egyes lépéseit, hanem értelmezzük is a lépések mögött megbúvó szándékot.Erre a szándékra ugyanúgy kényszerítő erővel hatnak a nyersanyagban fellépő fizikai-kémiai jellemzők, a készítő ember meghatározó tulajdonságai (motorikus képességei, megszerzett tapasztalatai), és az őt befogadó, magába foglaló közösség szokásainak összessége (Tixier, 2012, 39-42. o.).
$\mathrm{Az}$ egyes lépések mögött megbúvó szándék felfedésében nyújt segítséget az az elméleti háttér, amelyet az ún. paleoetnológiai iskola dolgozott ki a hatvanas évektől kezdődően (Delage, 2017). Ennek megfelelően több fázison keresztül vizsgálható az a folyamat, amíg egy elképzelésből megvalósul az eszköz a maga fizikai valójában. Első fázisként az elképzelést, az ötletet kell megvizsgálnunk, amelyhez a majdani tárgynak hasonlítania kell. A mentális kép, ami a készítő fejében létezik a tárgyról, annak méretéről, formájáról az elvi séma (schéma conceptuelle) (Inizan et al., 1999, 14-15. o.; Holló et al., 2004, 78. o.; Mester, 2014, 43. o.). A következő fázis annak az elméleti és gyakorlati tudásnak az összessége, ami az adott közösség tagjai számára rendelkezésre áll ahhoz, hogy ténylegesen el lehessen készíteni az adott 
produktumot. Ez a készítés különböző lépcsőfokait és a hozzájuk köthető gyakorlati tudnivalókat tartalmazza, és műveleti sémának (schéma opératoire) hívjuk. Ideális esetben a fenti két fázisnak megfelelően készül el az eszköz, ám a valóságban kevés ilyen eset létezik. A megvalósulás tényleges eseménysorát hivatott felfedni a műveletsor (châ̂ne opératoire) vizsgálata. A régészeti gyakorlatban mind a három fázisnak megvan a jellemző kutatási módszere: a morfometrikus statisztikai módszerek hivatottak felfedni az elvi sémát, a különböző technológiai kategóriák és azok arányainak vizsgálata segít a műveleti séma rekonstrukciójában, az egyes leletek és rajtuk lévő stigmák aprólékos vizsgálata pedig a műveletsorról nyújt fontos információkat (Mester, 2014, 45-47. o.).

Egy kész eszköz vizsgálatakor ugyanazt az utat tesszük meg, mint a készítője, csak éppen visszafele haladva. Először a konkrét műveletsort kell szemügyre vennünk az összes lépésével, fogásával együtt. Minél több kapcsolódó tárgyat tudunk vizsgálni, és azok minél több fázisról tanúskodnak, annál inkább megközelíthető a közösség elméleti eszközkészítő metódusa, a műveleti séma. Végezetül, ha az elkészült eszközök, formai, alaktani jellemzőit, és közös vonásait nézzük, akkor gyakorlatilag az elvi sémát látjuk magunk előtt.

\section{Lelőhely, leletanyag}

\section{Leletkontextus}

2005-től kezdődően két éven át a Vásárhelyi-tervhez kapcsolódóan az ELTE Régészettudományi Intézete és a Szolnoki Damjanich János Múzeum régészei közösen végeztek feltárásokat Rákóczifalvától délnyugatra, a Bagi föld nevezetű határrészen (Csányi et al., 2009, 2010)(1-2. ábra). Az 1/C lelőhely által érintett 100-120 méter széles, és mintegy kétszáz méter hosszú sávban Csányi Marietta és Tárnoki Judit vezetésével egy rézkori, Bodrogkeresztúri kultúrába sorolható települést és vele egykorú temetőt sikerült feltárni. Szeren- csés körülmény, hogy mind a település, mind a temető térben jól elkülönülten volt megfogható, így gyakorlatilag mindkettőt sikerült teljesen megkutatni. A település a vonatkozó sáv északnyugati sarkában található, a temető tőle délkeletre, mintegy 120-140 méteres üres rész után bukkant elő. Itt a szelvény középső részében szabályos két csoportba rendeződve 79 sírt tártak fel. A két sírcsoport közül a nyugati a nagyobb, itt többé-kevésbé szabályos ÉK-DNY irányú temetkezési sorokat lehetett megfigyelni. A keleti csoportba jóval kevesebb, mintegy tucatnyi sír tartozott. A legújabb eredmények alapján a két sírcsoportot eltérő időben, egymás után létesítették, a nyugati volt a korábbi (4345/4270 és 4300/4225 cal BC között), míg a keleti a későbbi (4250/4110 és 4150/4015 cal BC között)(Siklósi \& Szilágyi, 2020, Table 2). A települést 4380/4285 és 4295/4125 cal BC között használhatták, így inkább a nyugati sírcsoporttal mutat egyidejűséget.

Általánosságban véve a sírmellékletek száma és jellege a korábbi kutatásban már részletesen megismert rézkori Bodrogkeresztúr kultúra képet mutatta (Bognár-Kutzián, 1963; Patay, 1974). Ebből a szempontból fontos megemlíteni a jellegzetes, hálómintás ún. „tejesköcsög” alakú edényt, amely a sírok mintegy felében előfordult, vagy az arany lemezcsüngőket, a rézből készült csákányokat, tőröket és karpereceket (Csányi et al., 2009, 22-24. o.). Ez utóbbi leleteket archeometallurgiai vizsgálatnak is alávetették, melynek során bebizonyosodott, hogy a nyersanyaguk a szerbiai Majdanpek környékéről származik (Siklósi \& Szilágyi, 2019).

Áttérve a kőleletekre, itt is számos bizonyítékát lehetett találni a távolsági kapcsolatoknak. Az összesen 108 darab pattintott kőnek majdnem 60 százaléka a már említett volhíniai/pruti kovából készült. Egy további penge krakkói jura kovából készülhetett, ami körülbelül 350 kilométeres távolságot jelent a nyersanyag forrásától (Krajcarz et al., 2012). A leletanyag többi része, mintegy 30 

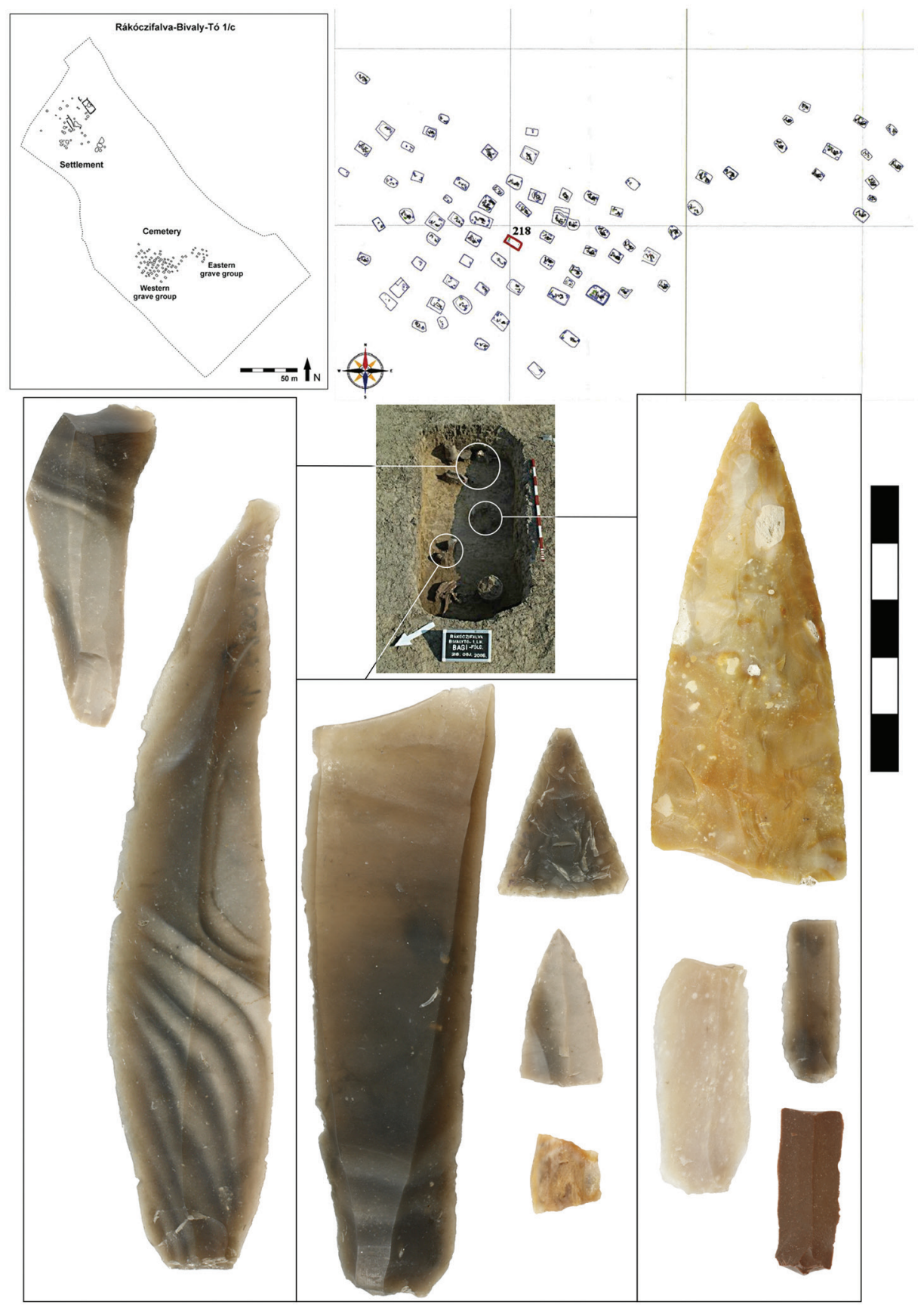

2. ábra. A telep, a temetkezési csoportok és a szimbolikus sír elhelyezkedése, illetve pattintott kő mellékletei (Csányi et al., 2009 és Siklósi \& Szilágyi, 2019 nyomán). 
darab az Északi-középhegységből eredeztethető, ezeknek vegyesen limnoszilicit vagy obszidián a nyersanyaguk (Mester \& Faragó, 2016; Szepesi et al., 2018), míg a dunántúli, bakonyi radiolaritokat négy darab képviselte (Szilasi, 2017). Déli irányú kapcsolatokra összesen két lelet utal, az egyikük bánáti kovából, a másik balkáni kovából készült. Az előbbi természetes előfordulásában több mint 200 kilométerre (Băltean, 2011), az utóbbi viszont akár több, mint 500 kilométerre található Rákóczifalvától (Gurova et al., 2016, Fig. 1).

A temetőben és a telepen előforduló darabok technológiai jellemzőiről röviden elmondható, hogy egyik helyen sem tükröződik intenzív kőeszköz készítés. Sehol nem volt jellemző a kérgesség, mint ahogy nem volt magkő, vagy magkőmaradék sem az egész lelőhelyen. Ugyanakkor két esetben is olyan törött pengét helyeztek a sírokba, amelyek nyelv alakú (languette) törés nyomait hordozták magukon, így szinte biztosan ugyanazon műhely és folyamat termékei.

A klasszikus tipológia szerint az együttes nagy többsége, 63 lelet eszköznek minősíthető. Közöttük a leggyakoribb típus a retusált penge, ebből 26 darab fordult elő. A második legnagyobb csoport a bifaciális hegyeké (13 darab), melyeknek a bázisa lehet egyenes vagy konkáv, viszont pár kivételtől eltekintve obszidiánból készültek. Ezek közül is az egyik magyarországi viszonylatban egyedülállónak számít, ugyanis a már említett szimbolikus sírból egy balkáni kovából készült, nagy méretű bifaciális levélhegy került elő.

Maga a sír a nyugati sírcsoport közepén helyezkedett el, nagyjából két sírsor között kihagyott kis térség közepén (2. ábra). A négyszögletes sírgödör keleti oldalánál hálómintás tejesköcsög és egy kisméretű csésze, valamint egy ellentett élű rézcsákány, rézár, állatmelléklet, egy nagyméretű és egy kisebb méretű penge volt. Nagyjából a sírgödör középső tengelyében voltak megtalálhatóak az egyéb pattintott kőeszközök, melyekből egyébként az említett levélheggyel együtt összesen 10 darab került elhelyezésre nagyjából három, elkülönülő csoportra bontva. Ezek között volt bifaciális hegy, háromszög alakú unifaciális hegy, trapéz, retusált és ép pengék. Egy-egy esetben limnoszilicitből és radiolaritból is készültek darabok, de nagyobb részt volhíniai kova tárgyak kerültek a sírba. A nyugati oldalnál egy bütyökdíszes edény és további állatcsontok kerültek kibontásra. Emberi maradványok ugyan nem kerültek elő, de a réztárgyak és a pattintott kőeszközök együtt mégiscsak egy jelképes férfisírt valószínűsítenek (Csányi et al. 2009, 25. o.). Kőeszköz ugyanis három kivétellel csak férfiakkal került eltemetésre, és csak négy olyan férfi ismert, akik mellett nem volt ilyen tárgy. Bifaciális hegy azonban kizárólag csak a férfiak attribútuma volt, ilyen tárgyból pedig a vonatkozó sírban kettő is előfordult. Az egyikük a korszakban szokványosnak mondható kisebb méretű hegyek közé sorolható, a másik, nagyméretű bifaciális levélhegy azonban unikális a magyarországi rézkor vonatkozásában.

\section{A tárgy leírása és klasszikus tipo-kronológiai meghatározása}

Megnevezés: Sárgás szinü, fehér foltos kovából (balkáni kova) készült bifaciális levélhegy töredéke (2-3. ábra).

Leírás: Nyújtott, szabályos háromszög alakú, ovális keresztmetszetü, mindkét éle enyhén ivelt, domború, bázisánál átlósan törött, részben eldolgozott, előlapján és hátlapján is bifaciális retussal megmunkált levélhegy töredéke. Nyersanyag: kő (balkáni kova)

Méretek (hossz. $\times$ szél. $\times$ vas.): $86 \times 35 \times 7 \mathrm{~mm}$.

A tárgy megnevezése szándékosan nem nyílhegy, lándzsahegy, vagy akár tőr, mivel ezek a terminusok már egyúttal valamilyen használatbeli sajátosságra is utalnak. A tényleges funkció meghatározása azonban még használati nyom elemzéssel is problémás, ráadásul tipológiailag, metrikusan sem egyértelmű a határvonal a nyílhegyek és lándzsahegyek között (Boyadzhiev, 
2015, 108-109. o.). A sírban elfoglalt pozíció némiképp utalhat az egykori használatra, de akár tovább is növelheti a zavart, hiszen ez a levélhegy a sír tengelyéhez közel, középen bukkant elő. Ha elfogadjuk azt az interpretációt, hogy a sírunk egy férfisírt szimbolizál, akkor a hegyünk derék tájékon, heggyel a lábak felé került elhelyezésre.

A levélhegy nyersanyagául szolgáló balkáni kova megnevezése egészen az elmúlt évtizedig sok félreértésre adott okot (Biagi \& Starnini, 2010, 124. o.; Gurova, 2012, 15-19. o., 2018). A szakirodalomban számos néven felbukkanó (Pre-Balkan platform flint, Balkan flint, honey-brown flint, Banat flint, silex blond) méz-sárgás, fehér pöttyöket, foltokat tartalmazó nyersanyagon nem minden kutató értette feltétlenül ugyanazt, miközben a kőzet pontos eredete is kérdéses volt egészen kétezres évekig. Az elmúlt évtizedekben elvégzett kutatások szerint Bulgáriában többféle kovás kőzet megtalálható, melyek közül balkáni kován egyrészt érthetjük az Elő-Balkán részét képező Bolgár-tábla területén előforduló, felső kréta időszakból (Campaniai és Maastrichti emelet) származó kovás nyersanyagokat (moesiai kova). Másrészt, ugyanezen a Bolgár-tábla területen makroszkopikusan nagyon hasonló, ám eltérő geológiai korú, alsó kréta (Apti emelet) kőzetek is előfordulnak (ludogorie/dobrudzsa kova) (Gurova, 2012, 27-28. o.). Az eddigi geokémiai és műszeres vizsgálatok egyértelműen bebizonyították, hogy a Duna menti Nikápoly/Nikopol tágabb régiójából származó moesiai kovás kőzeteket biztosan használták a bulgáriai kora neolitikumtól kezdődően egészen a késő neolitikumig, így bizonyos vélemények szerint ez nevezhető balkáni kovának (Gurova et al., 2016, 2018). Ugyanakkor, az északkelet bulgáriai eredetű, tehát távolabbi ludogorie/dobrudzsa kovához köthetőek a bulgáriai rézkorban elterjedt, nyomásos technikával előállított „,szuper-pengék”, melyek a várnai sírokat és a korszakhoz tartozó telleket is egyaránt jellemzik (Biagi \& Starnini, 2010; Gurova, 2016b). A kérdés, hogy vajon melyik nyersanyag variánshoz köthető a rákóczifalvi levélhegy jelen pillanatban nem dönthető el, így a leghelyesebb, ha a meghatározása marad egyszerűen balkáni kova.

A tárgy tipológiai besorolása szintén problémás, hiszen a párhuzamként szolgáló különböző bulgáriai típusok tisztán morfológiai jegyek alapján lettek elkülönítve (Boyadzhiev, 2015, 173-174. o.; Lichardus \& Lichardus-Itten, 1993, 24-26. o.). A vizsgálatunk tárgya viszont törött, így az egyik legfontosabb tipológiai jegy, a bázis jellege, illetve a bázis közelében az oldalélek kialakítása nem vizsgálható teljes terjedelmében. Mégis, több érv is szól amellett, hogy a levélhegy Kamen Boyadzhiev rendszerében a IV. vagy a VI. csoportba tartozik. Egyrészt, ezeknél a típusoknál az élek konvexitása, általános ívelődése megegyezik a rákóczifalvi darabéval, másrészt a IV. csoport a leggyakoribb a bulgáriai területeken az összes előkerült levélhegyet tekintve (30\%).

\section{A bifaciális levélhegy technológiai vizsgálata}

A műveletsor vizsgálata során a levélhegy mindkét oldalán a leválasztások időbeli sorrendje került meghatározásra (4. ábra). Az ábrán megjelenő színek kronológiai sort jelentenek, vagyis minél sötétebb az eszközökön egy-egy leválasztás tónusa, az annál később történhetett meg. Ez az egymás mellett lévő, szomszédos leválasztások esetében a lépések pontos egymásutániságát jelenti, hiszen ott megállapítható a formálás pontos sorrendje. Ugyanakkor minél távolabb vannak egymástól az egyes negatívok, annál nehezebb megállapítani az egymáshoz való időbeli viszonyukat. Egymással kapcsolatban nem álló, távoli leválasztások esetén a színek csak tájékoztató jellegűek, a lehetséges legkorábbi időpontját jelentik az adott leütésnek. Ennek megfelelően az egyforma színű, távoli negatívok nem jelentenek feltétlenül egyidejűséget. Ebből a szempontból a tárgy két oldala közötti kronológiai viszonyt sem lehet egyértelműen tisztázni. 
Az elemzést a 4. ábra bal oldalán kezdve, a legkorábbi leválasztás (világos színnel) az eszköz alsó harmadában, középen, jobb oldalról indítva, átlósan húzódik. Noha ez a szilánk a jobb oldali él irányából került leütésre, az ezt követő leválasztások mind a bal oldali él felől történtek, vagyis a készítő fokozatosan haladt az eszköz csúcsa felé. A túloldalon, a jobb oldali élen folytatva az ellenkező irányba határozottabb időrendiség bontakozott ki, itt a negatívok egyértelműbben követték egymást, egészen az él középső szakaszáig. Itt látszik, hogy további kiigazításokra volt szükség, úgyhogy itt rengeteg további negatív követte egymást. Ezekkel a leválasztásokkal egy időben a jobb oldali él felől a bázis közelében is megtörtént a levélhegy további elvékonyítása. A középső részről elindulva történt meg az él középső ívének a kialakítása, egyúttal a csúcs felé haladva a végső retusálása. A bal oldali élen, részben ezzel egy időben, részben kicsivel utána egy teljesen más stratégia bontakozott ki, itt a legkorábbi, nagyobb szilánkok úgy látszik, pont a megfelelő formára vékonyították el a levélhegyet, úgyhogy csak rövid, szakaszos kiigazításokra volt csak szükség, melyet három etapra lehetett bontani. Ezek közül kettő egyértelműen a csúcs felől haladt a bázis irányába. A végső retusálás ezen az oldalon szintén csak rövid szakaszokat érintett, és csak eseti jellegű volt.

A másik oldal kialakítása első pillantásra és nagy vonalakban ugyanilyen metódus szerint történt, ami a pattintó begyakorlott, megtanult sémájára utal. Ugyanakkor közelebbről megvizsgálva érhető tetten az a magas fokú szakértelem, ahogy a pattintó a vélhetően évtizedes tapasztalatára támaszkodva az eszköz készítése közben adaptálódott a változó körülményekhez. A haladási irány itt is a bal él felől indult, majd a csúcshoz közelebb a jobb oldalon folytatódtak a leválasztások, egészen a jelenlegi bázisig. A kiigazítások újra a középső szakaszt érintették, itt a csúcs felől indult el egy hosszabb, majd egy rövidebb elvékonyító szakasz. Harmadszor újra a középső szakaszt kel- lett retusálni, illetve a disztális véget kellett végső formájára alakítani. A bal oldali él szintén időben kicsit későbbre tolódva nyerhette el végső formáját, itt a csúcshoz közel kicsit több alakításra volt szükség, mint az előző oldalon, mindenesetre újra a szakaszos, legyező-szerü vékonyítást figyelhetjük meg. A bázis közelében ezen az élen az előző oldal finom beavatkozásai köszönnek vissza, majd az él végső, szakaszos retusálással fejeződött be az eszköz készre alakítása.

A műveletsor azonban itt nem fejeződik be, hanem további eseményekkel tudjuk kiegészíteni, amelyek időben akár több évvel is követhették az eszköz elkészültét. A jelenlegi bázisánál, az egyik oldal felől egy merőleges erőhatás érte a levélhegyet, aminek következtében átlósan eltört a darabunk. A megmaradó és árulkodó párkányt kisebb leütésekkel, preparálásokkal próbálták eltüntetni, vagy részben tompítani.

A műveleti séma rekonstrukciójához további tárgyakra lenne szükségünk, amelyek felfednék a készítés pontos menetét. Ezek lehetnek nyersanyagdarabok, különböző készítési fázisban félbemaradt félkész és rontott darabok, kisebb-nagyobb leválasztott szilánkok és elhasznált, törött levélhegyek. Ezen a lelőhelyen, sem a sírokban, sem a telepen ilyen darabokkal egyáltalán nem rendelkezünk. Számba véve a két oldalon összesen látható negatívokat (269 darab!), és hozzászámolva azokat, amelyek már nem látszanak, könnyen belátható, hogy egy ilyen levélhegy elkészítése jelentős mennyiségű melléktermékkel jár együtt. Ugyanakkor más, ebből a szempontból gazdagabb régiók és lelőhelyek megjelent közlései, valamint a kísérleti régészet tapasztalatai alapján ismert az a többé-kevésbé kötött folyamat, ami egy levélhegy előállításához szükséges. Az egyik, skandináviai bifaciális tárgyakhoz köthető kísérleti régészeten alapuló műveleti séma a következőképpen néz ki (Apel, 2008, 103. o., Fig. 3-4).Az első fázisban alkalmas nyersanyagdarabokra van szükség, amelyek meghatározott formával és mérettel ren- 

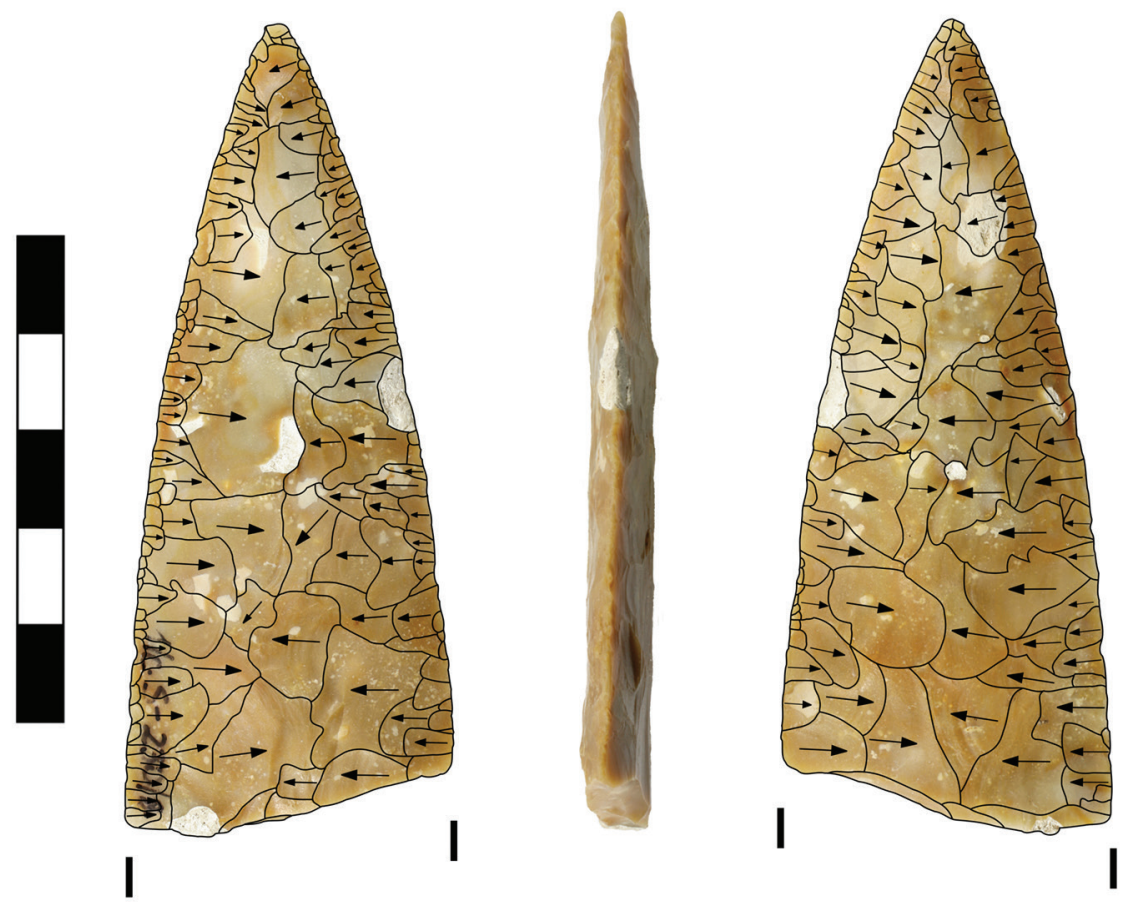

3 ábra. A balkáni kovából készült bifaciális levélhegy. Ávra: Faragó Norbert.

delkeznek. A második fázisban egy körbefutó élt kell kialakítani a nyersanyagdarab körül. A harmadik fázisban el kell érnünk, hogy a darabunk lencse keresztmetszetet vegyen fel, vagyis kellően el kell vékonyítanunk. Minél jobban teljesül ez a feltétel, annál egyszerűbb a további munka a negyedik fázisban, amikor is folytatódik a darabunk arányos elvékonyítása, így elnyeri végső keresztmetszetét és szimmetrikus kontúrját, miközben a szélesség-vastagság arány 4:1 és 5:1 értékek között marad. A gyakorlati tapasztalatok alapján ennek a fázisnak a sikeres kivitelezése az egyik legnehezebben elsajátítható, évtizedes gyakorlásra van szükség hozzá. A legutolsó fázis esetünkben - mivel ezeken a darabokon rendszerint nincsen nyél, és nincsen rajtuk párhuzamos felületi megmunkálás - az él finom kialakítása a kívánt formára, ehhez retusálásra van szükség.
A rákóczifalvi bifaciális hegyen érthető módon az első és a második fázis nem figyelhető meg, hiszen a későbbi alakítások ezeknek a nyomait mind eltávolították (3. ábra). A harmadik fázis elvékonyító hatását úgy tudjuk azonosítani, ha olyan leválasztásokat keresünk a konkrét darabon, amelyek a tárgy középvonalán túlfutnak. Mindkét oldalon a legkorábbi negatívok ugyan rendelkeznek ilyen jellemzővel, de ezek tartozhatnak a negyedik fázis elvékonyító lépései közé is. A konkrét eszköz készítője általában a csúcs felé haladt ebben a fázisban, legalábbis a kevés, nagy leválasztásokat tekintve ez tűnik a valószínűbbnek. Az őket követő leválasztások már a szimmetrikus forma kialakítására közvetlenül irányuló leválasztások nyomai. A pattintó a negyedik fázisban már inkább a csúcs felől haladt a bázis felé, és óvatosan, rövid szakaszokban, legyező-szerűen 

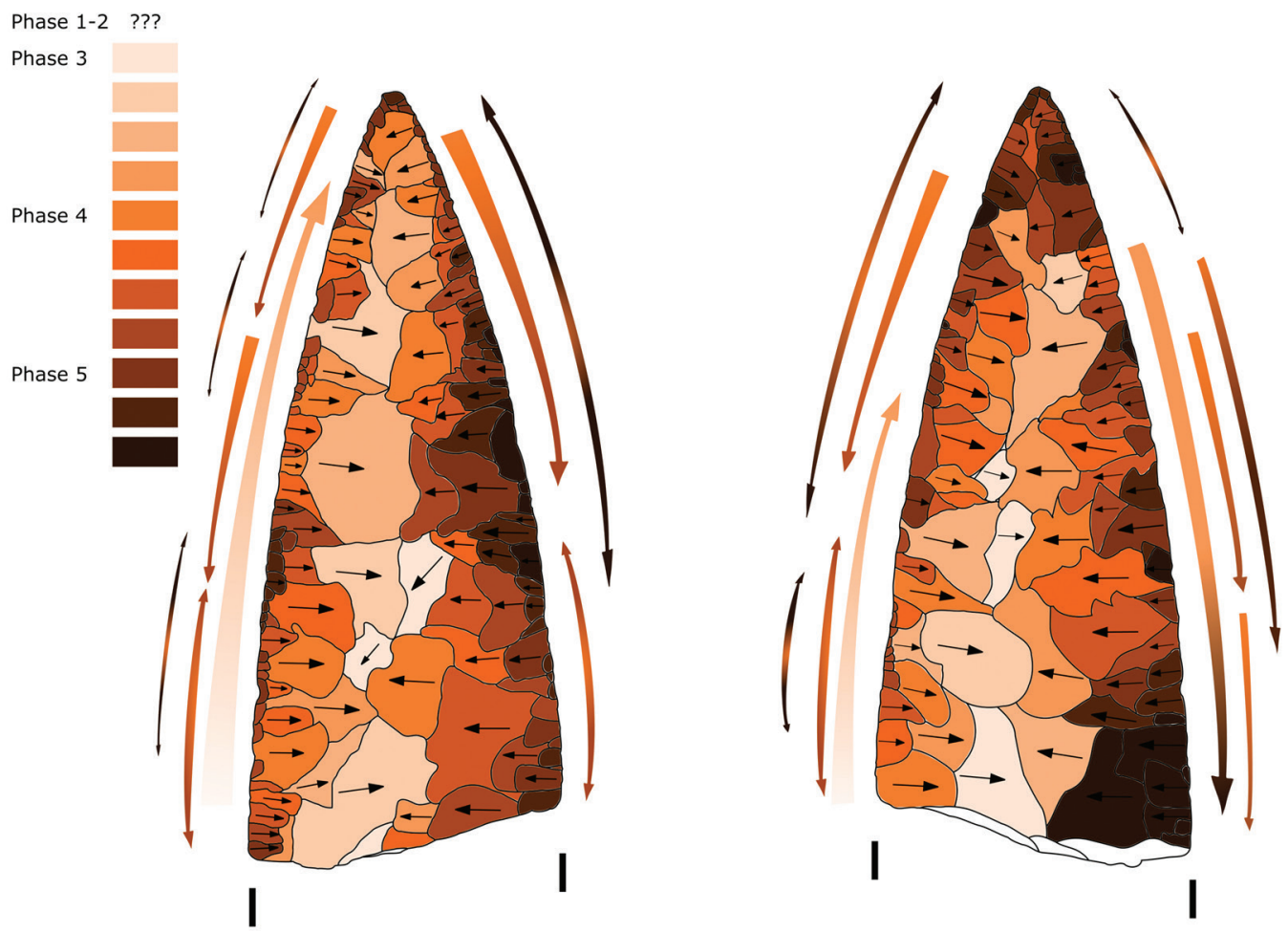

4. ábra. A készítés fázisai (1., megfelelő nyersanyag kiválasztása, 2., körbefutó, koncentrikus él kialakítása, 3., lencse keresztmetszet elérése, 4., elvékonyítás, 5., végső kialakítás) és a leválasztások időrendi sorrendje. Ábra: Faragó Norbert.

szétterülő leválasztás csoportokkal vékonyította el a végső formára a levélhegyet, miközben elkerülte, hogy a vastagsága helyett a szélességéből veszítsen az eszköz. A metódus sikeressége abban is látszik, a legvégső, ötödik fázis retusálása már csak az élek végső simításait jelentették, egyáltalán nem volt rájuk mindenhol szükség. Végeredményül, ha megvizsgáljuk a konkrét tárgyunk szélesség-vastagság arányát, akkor pont a kívánt 5:1 arányt kapjuk.

Az elméleti séma megközelítéséhez a levélhegy arányait, formáját érdemes szemügyre vennünk. Ehhez a legtöbb esetben szintén több tárgyra van szükségünk, hiszen nem feltétlenül lehetünk tisztában azzal, hogy az elkészült termék pontosan olyan lett, mint amilyennek a készítője megálmodta. Sorozatban készült tárgyak esetében azonban a kivitelezés közelíteni fog egy elméleti átlaghoz, ami viszont az elvi sémát fogja tükrözni. Ebben az esetben nincs több hasonló tárgyunk a lelőhelyről, viszont szinte biztosak lehetünk benne, hogy az elkészült forma híven tükrözi a készítő fejében lévő képet. Erre bizonyíték a levélhegy alakja, ami szinte minden oldalról tökéletesen szimmetrikus önmagával (3. ábra). Az egyetlen kivétel oldalnézetből adódik, ebben az esetben egy enyhe hajlást figyelhetünk meg az egyik lap irányába, így a levélhegy ebből a szögből enyhe aszimmetriát mutat. Természetesen ez nem jelenti azt, hogy az aszimmetria nem lehet tudatos szándék eredménye, viszont a szimmetria szinte biztosan nem véletlen. 


\section{A lelet párhuzamai kárpát-medencei viszony- latban és azon túl}

A magyarországi lelőhelyeket számba véve a bifaciális hegyek, amelyeken az előkerült tárgyak alapján kizárólagosan nyílhegy méretű tárgyakat értünk, és hagyományosan a Bodrogkeresztúri kultúra időszakára keltezhetőek (Patay, 1979, 37. o.). Az egyetlen enigmatikus kivétel Bükkábrány-Bánya VII. lelőhelyén a 4. objektumból előkerült tökéletes állapotú, bifaciális kidolgozású obszidián hegy, melyet egyértelműen az Alföldi Vonaldíszes kerámia kultúrájának legelső, kialakuló fázisára lehetett keltezni (Faragó et al., 2015, Fig. 9). Különlegességét csak fokozza, hogy nem csak Magyarország területén, hanem tágabb régiónkban, Közép- és Kelet-Európában illetve a Balkánon is hasonló kidolgozású hegyek egységesen a neolitikum végétől, a rézkor legelejétől figyelhetőek csak meg. (Csongrádiné Balogh, 2000, Boyadzhiev, 2014, 121-123. o.; Lichardus \& Lichardus-Itten, 1993, 47-48. o.).

A hazai, rézkori bifaciális hegyekről általánosságban elmondható, hogy nagyobbrészt a Bodrogkeresztúri kultúrára jellemzőek, szinte mindegyikük temetkezésben fordult elő, és szinte mindegyikük obszidiánból készült. (Patay, 1979, 37. o.; Marton, 2011, 167-168. o.). Az Alföldön helyinek tekinthető nyersanyag ellenére ez a tárgytípus és technológia, mint láthattuk, nem rendelkezik helyi előzményekkel. Az egyetlen magyarországi lelet, amely a rákóczifalvi levélhegyünkkel rokonítható, az egy Szelevény-Öthalomról származó, volhíniai/pruti kovából készül szórványlelet (Patay, 1958; Csongrádiné Balogh, 2001, 94, 98. о.).

Tágabb kitekintéssel megvizsgálva a hasonló levélhegyeket, a Magyarországhoz közelebb eső Északnyugat Bulgáriában a már korábban említett IV. típus, együtt az V. típussal szinte kizárólagos arányban fordul elő (90\%)(Boyadzhiev, 2015, 122. o.). Itt, főleg Lovecs régióban számos szórványlelet került elő az elmúlt évtizedekben, ami helyi előállítási központot valószínűsít. Ami viszont mindenképpen érdekes, az a leletünk előkerülési kontextusa, hiszen egész Bulgáriában ezek a darabok szinte majdnem mindig temetőkön kívül, barlangokban, településeken vagy akár telleken kerültek elő (Boyadzhiev, 2015, 174. o.). A négy kivétel a Várna I. temető 43. és 97. sírjai, a Durankulak temető 597. számú temetkezése (Boyadzhiev, 2015, 123. o.), illetve a Reka Devnja-i sír (Lichardus \& Lichardus-Itten, 1993). Ezek mindegyike Északkelet Bulgáriában található, ráadásul közöttük is a 97. sír kenotáfiumként volt meghatározva. Kronológiailag a legtöbb levélhegy a bulgáriai rézkor kései szakaszára (4500/4400-4100/3800 cal BC), annak is inkább a középső és utolsó harmadára keltezhető. Kulturálisan ez a Krivodol-Sălcuţa-Bubanj Hum 1a és Kodžadermen-Gumelniţa-Karanovo VI időszakkal párhuzamosítható.

Hasonló technológiai vizsgálat még nem történt a hazai, vagy akár balkáni rézkori bifaciális hegyekhez kapcsolódóan, így egyelőre sajnos nincs mód arra, hogy eltérő szaktudású mesterembereket, tradíciókat kövessünk nyomon. Egy pozitív példa a nemzetközi kutatásban viszont létezik a skandináviai késő neolitikumból (23501500 cal BC), ahol is regionális szinten sikerült megvizsgálni, hogy milyen lelőhelyeken történt a nyersanyag előkészítése, az elsődleges és másodlagos forma, illetve a végső eszköz kialakítása (Apel, 2008, 106-108. o.). A lelőhelyenként előkerülő melléktermékek és hulladékok számba vétele mellett intenzív kísérleti régészeti módszerekkel határozták meg az egyes készítési fázisokat és azok nehézségi fokát. A kutatás meglepő eredménye az volt, hogy a legkönnyebben elvégezhető, korai készítési fázisokat a nyersanyagforrásokhoz közel, a településektől távol, eldugottabb helyeken végezték. Mindeközben a nagy gyakorlati tudást és tapasztalatot igénylő, látványosabb készítési fázisokat a végső felhasználási helyhez közel, a forrástól akár több száz kilométerre a településeken, kvázi reprezentatív módon gyakorolták. 


\section{Összegzés}

A rákóczifalvi levélhegy lelőkörülményei, nyersanyaga, tipokronológiai párhuzamai és technológiai elemzése mind amellett szólnak, hogy ez a tárgy nem a Kárpát-medencében készült, hanem valahol Észak-Bulgáriában. Ugyanakkor, a távoli készítés ellenére az Alföldön is találkozott az a magas fokú tudás, amely egy ilyen levélhegy elkészítéséhez szükséges ugyanazzal a kulturális, társadalmi háttérrel, amelyben ezek a tárgyak értelmet nyertek. Így ez a levélhegy is ugyanolyan kiemelt szerepet kapott az egykori közösségben, mint a bulgáriában maradt hasonló tárgyak. Mindez, itt a Kárpát-medencében csak a korszakban már többször bizonyított európai léptékú kapcsolatrendszernek lehetett köszönhető (Pétrequin et al., 2017, Fig. 12), melynek következményeképp a rákóczifalvi lándzsahegy a bulgáriai rokon tárgyakkal hasonló kivitelezésben, hasonló kulturális értelmezésben, szinte egy időben képezte a részét a közösség életének.

A nemzetközi, de akár a hazai paleolit kutatásban is számos tanulmány bizonyítja, hogy érdemes a bifaciális eszközök készítését a műveletsor megközelítés szemszögéből vizsgálni (Szolyák \& Lengyel 2014). Sőt, a debitage és a retusálás műveletekkel szemben a formálás tárgykörébe tartozó lépések azok, amelyek igazán demonstratív módon, egyetlen darab pattintott kövön tudják megmutatni ennek a módszernek az igazi erejét, legalábbis ha az őskori eszközkészítést akarjuk tetten érni. Nyersanyag és tipológiai szempontból már több elemzés is foglalkozott ezekkel a tárgyakkal (Csongrádiné Balogh, 2000), ám részletes, készítéstechnológiai szempontok ezidáig csak korlátozottan merültek fel (Marton, 2011). Egy ilyen vizsgálat új szempontokat világíthat meg a készítés helyét és a készítés személyét illetően, hiszen ezidáig a hazai kutatásban az az óvatos vélemény fogalmazódott meg, hogy a helyi, vagyis kárpát-medencei nyersanyag (obszidián) miatt ezek a bifaciális hegyek nem lehetnek import darabok, és így talán a bifaciális technológia is helyben került újra feltalálásra (Marton, 2011, 168-169. o.). További tárgyak részletes technológiai vizsgálatával lehetőség nyílik különböző eszközkészítési tradíciókat is rekonstruálni, vagy akár készítési régiókat is elkülöníteni.

\section{Technological observations on the bifacial leafpoint from the cemetery of Rákóczifalva}

The subject of this study is a bifacial leaf point found in the symbolic grave no. 218/230 at the site of Rákóczifalva-Bivaly-tó $1 / \mathrm{C}$. In the lack of use-wear analysis the denomination „bifacial leaf point" seemed more accurate, as other terms, such as arrowhead, spearhead, or dagger are rather functionally determined. Besides, the description of the find and its archaeological context, and the outline of the possible analogies, the study focuses to an exhaustive technological analysis.

This analysis relied on the detailed observation of the consecutive steps and techniques realized during production. The main goal was to directly shed light on the circumstances of the preparation, the location, and the maker of this artefact. Indirectly, the study offers additional clues on the extended contacts and the technological innovation experienced during the Copper Age. According to the results, it can be excluded that this leaf point was manufactured on-site, but its raw material together with high-quality craftsmanship and cultural tradition manifested in its find context represents strong connections with Northern Bulgaria.

\section{Köszönetnyilvánítás}

Jelen tanulmány a Bolyai János Kutatási Ösztöndíj támogatásával valósult meg.

\section{Felhasznált irodalom}

Apel, J. (2008). Knowledge, Know-how and Raw Material-The Production of Late Neolithic Flint Daggers in Scandinavia. Journal of Archa- 
eological Method and Theory, 15(1), 91-111. https://doi.org/10.1007/s10816-007-9044-2

Bácskay, E. (1989). A lengyeli kultúra néhány DK-dunántúli lelőhelyének pattintott kőeszközei. Communicationes Archaeologicae Hungariae, 41, 5-21.

Bácskay, E. (1990). A lengyeli kultúra pattintott kőeszközei a DK-Dunántúlon II. Communicationes Archaeologicae Hungariae, 42, 59-66.

Băltean, I. C. (2011). Some remarks on the rock types used in Prehistory. In F. Draşovean \& B. Jovanović (Szerk.), The Prehistory of Banat (pp. 32-33). Editura Academiei Române.

Biagi, P., \& Starnini, E. (2010). The early Neolithic chipped stone assemblages of the Carpathian Basin: Typology and raw material circulation. In Janusz Krzysztof Kozłowski \& P. Raczky (Szerk.), Neolithization of the Carpathian Basin: Northernmost distribution of the Starcevo/Körös Culture. Papers presented on the Symposium organized by the EU Project FEPRE (pp. 119-136). Polska Akademia Umiejętności.

Bognár-Kutzián, I. (1963). The Copper Age cemetery of Tiszapolgár-Basatanya. Akadémiai Kiadó.

Boyadzhiev, K. (2015). Въоръжение През Халколита В Българските Земи [Weapons from the Chalcolithic period in Bulgaria]. National Institute of Archeology with Museum.

Crandell, O., \& Vornicu, D. M. (2015). Aspects of Long Distance trade by the Precucuteni Culture. Transylvanian Review, 24(2), 85-108.

Csányi, M., Raczky, P., \& Tárnoki, J. (2009). Előzetes jelentés a rézkori Bodrogkeresztúri kultúra Rákóczifalva-Bagi-földön feltárt temetőjéről. Tisicum. A Jász-Nagykun-Szolnok Megyei Múzeumok Évkönyve, 18, 241-270.

Csongrádiné Balogh, É. (2000). Rézkori pattintott kőeszközök a Magyar Nemzeti Múzeumban. Communicationes Archaeologicae Hungariae, 20, 49-66.

Csongrádiné Balogh, É. (2001). Adatok a rézkori, bronzkori pattintott kőeszközök tipológiai ér- tékeléséhez (Jász-Nagykun-Szolnok megye). Tisicum. A Jász-Nagykun-Szolnok Megyei Múzeumok Évkönyve, 12, 91-104.

Delage, C. (2017). Once upon a time...the (hi)story of the concept of the chaîne opératoire in French prehistory. World Archaeology, 49(2), 158-173. https://doi.org/10.1080/00438243.201 7.1300104

Fábián, S., Marton, T., \& Oross, K. (2007). Újkőkori temetkezés Balatonszárszóról. In K. Belényesy, S. Honti, \& S. Kiss (Szerk.), Gördülő idöRégészeti feltárások az M7-es autópálya Somogy megyei szakaszán Zamárdi és Ordacsehi között (pp. 90-92). Somogy Megyei Múuzeumok Igazgatósága, MTA Régészeti Intézete.

Faragó, N. (2017). Differences in the selection of raw materials at the site of Polgár-Csőszhalom, northeast Hungary. Bulgarian e-Journal of Archaeology, 7, 85-115.

Faragó, N. (2019). Complex, household-based analysis of the stone tools of Polgár-Csőszhalom. Dissertationes Archaeologicae ex Instituto Archaeologico Universitatis de Rolando Eötvös nominatae Ser. 3, 7, 301-329.

Faragó, N., Tutkovics, E., \& Kalli, A. (2015). Előzetes jelentés Bükkábrány-bánya, VII. lelőhely pattintott kőeszköz anyagáról. A Herman Ottó Múzeum Évkönyve, 54, 25-37.

Gábori, M. (1976). Les civilisations du paléolithique moyen entre les Alpes et l'Oural: Esquisse historique (French Edition). Akadémiai Kiadó.

Gronenborn, D. (1997). Silexartefakte der ältestbandkeramischen Kultur. Habelt.

Gurova, M. (2012). 'Balkan flint' - fiction and/or trajectory to Neolithization: Evidence from Bulgaria. Bulgarian e-Journal of Archaeology, 1, 15-49.

Gurova, M., Andreeva, P., Stefanova, E., Stefanov, Y., Kočić, M., \& Borić, D. (2016). Flint raw material transfers in the prehistoric Lower Danube Basin: An integrated analytical approach. Journal of Archaeological Science: 
Reports, 5, 422-441. https://doi.org/10.1016/j. jasrep.2015.12.014

Gurova, M., Chabot, J., \& Chohadzhiev, S. (2016). Chalcolithic superblades from Bulgaria: A case study of a recently found hoard from Sushina. Bulgarian E-Journal of Archaeology, 6(2), 165-190.

Holló, Zs., Lengyel, Gy., Mester, Zs., \& Szolyák, P. (2004). Egy pattintott kőeszköz vizsgálata. Magyar kifejezések a technológiai vizsgálatokhoz 3. Ösrégészeti Levelek, 6, 62-80.

Inizan, M.-L., Reduron-Ballinger, M., Roche, H., \& Féblot-Augustins, J. (1999). Technology and terminology of knapped stone: Followed by a multilingual vocabulary, Arabic, English, French, German, Greek, Italian, Portuguese, Spanish. Cercle de Recherches et d'Etudes Préhistoriques.

Kaczanowska, M. (1985). Rohstoffe, Technik und Typologie der neolithischen Feuersteinindustrien im Nordteil des Flussgebietes der Mitteldonau. Państwowe Wydawnictwo Naukowe.

Kaczanowska, M., \& Kozłowski, J. K. (2015). Raw Materials Circulation, Organization of Production and Lithic Technology in the Neolithic/ Early Copper Age Transition. In S. Hansen, Raczky Pál, Anders Alexandra, A. Reingruber, Eötvös Loránd Tudományegyetem, \& Deutsches Archäologisches Institut (Szerk.), Neolithic and Copper Age between the Carpathians and the Aegean Sea: Chronologies and Technologies from the 6th to the 4th Millennium BCE; International Workshop Budapest 2012 (pp. 93-104). Habelt.

Kaczanowska, M., Kozłowski, J. K., \& Sümegi, P. (2009). Lithic industries from the Öcsöd-Kováshalom tell-like settlement in Hungary. In F. Draşovean, D. L. Ciobotaru, \& M. Maddison (Szerk.), Ten years after: The neolithic of the Balkans, as uncovered by the last decade of research. Proceedings of the Conference held at the Museum of Banat on November 9th-10th, 2007 (pp. 125149). Editura Marineasa.
Kozłowski, Janusz K., Mester, Zs., Zandler, K., Budek, A., Kalicki, T., Moskal, M., \& Ringer, Á. (2009). Le Paléolithique moyen et supérieur de la Hongrie du nord: Nouvelles investigations dans la région d'Eger. L'Anthropologie, 113(2), 399-453. https://doi.org/10.1016/j.anthro.2009.04.005

Krajcarz, M. T., Krajcarz, M., Sudoł, M., \& Cyrek, K. (2012). From far or from near? Sources of Kraków-Częstochowa banded and chocolate silicite raw material used during the Stone Age in Biśnik Cave (southern Poland). Anthropologie (Brno), 50(4), 411-425.

Lengyel, Gy., \& Mester, Zs. (2008). A new look at the radiocarbon chronology of the Szeletien in Hungary. Eurasian Prehistory, 5(2), 73-83.

Lengyel, Gy., Mester, Zs., \& Szolyák, P. (2016). The Late Gravettian and Szeleta Cave, northeast Hungary. Quaternary International, 406, 174-183. https://doi.org/10.1016/j.quaint.2015.09.014

Lichardus, J., \& Lichardus-Itten, M. (1993). Das Grab von Reka Devnja (Nordostbulgarien). Ein Beitrag zu den Beziehungen zwischen Nord- und Westpontikum in der frühen Kupferzeit (pp. 2-99). Habelt.

Marton, T. (2011). Chipped stone arrowheads in the Neolithic and the Copper Age in the Carpathian Basin. In Gy. Kovács \& G. Kulcsár (Szerk.), Ten thousand years along the Middle Danube, Life and Early Communities from Prehistory to History (pp. 165-178). Archaeolingua.

Mester, Zs. (2014). Technologie des pièces foliacées bifaces du Paléolithique. In K. T. Biró, A. Markó, \& K. Bajnok (Szerk.), Aeolian scripts, New ideas on the lithic world, Studies in honour of Viola T. Dobosi (pp. 41-62). Magyar Nemzeti Múzeum.

Mester, Zs., \& Faragó, N. (2016). Prehistoric exploitation of limnosilicites in Northern Hungary: Problems and perspectives. Archaeologia Polona, 54, 30-50. 
Mester, Zs., \& Kozłowski, J. K. (2014). Modes de contacts des Aurignaciens du site d'Andornaktálya (Hongrie) á la lumière de leur économie particuliere de matieres premières. In M. Otte \& F. Le Brun-Ricalens (Szerk.), Modes de contacts et de déplacements au Paléolithique eurasiatique $=$ Modes of contact and mobility during the Eurasian Palaeolithic, Actes du Colloque international de la commission 8 (Paléolithique supérieur) de l'UISPP, Université de Liège, 28-31 mai 2012 (pp. 349-367). Université de Liège.

Mester, Zs., \& Rats, A. (2010). The spread of the Körös Culture and the raw material sources in the northeastern part of the Carpathian basin: A research project. In Janusz Krzysztof Kozłowski \& P. Raczky (Szerk.), Neolithization of the Carpathian Basin: Northernmost distribution of the Starcevo/Körös Culture. Papers presented on the Symposium organized by the EU Project FEPRE (pp. 23-35). Polska Akademia Umiejętności.

Oravecz, H. (1996). Neolithic burials at Tiszalúc-Sarkad. Folia Archaeologica, 51-62.

Oross, K., \& Marton, T. (2012). Neolithic burials of the Linearbandkeramik settlement at balatonszárszó and their european context. Acta Archaeologica Academiae Scientiarum Hungaricae, 63(2), 257-299. https://doi.org/10.1556/ aarch.63.2012.2.1

Patay, P. (1958). La pointe de lance de szelevény. Folia Archaeologica, 10, 29-33.

Patay, P. (1974). Die hochkupferzeitliche Bodrogkeresztur-kultur. Bericht der Römisch-Germanischen Komission, 55, 3-71.

Patay, P. (1979). A Tiszavalk-tetesi rézkori temető és telep (Kupferzeitliches Gräberfeld und Siedlung von Tiszavalk-Tetes). Folia Archaeologica, 30, 27-51.

Pétrequin, P., Pétrequin, A.-M., Gauthier, E., \& Sheridan, A. (2017). Mécanismes sociaux:les interprétations idéelles des jades alpins Social mechanisms:the ideological interpretations of Al- pine jade artefacts (P. Pétrequin, E. Gauthier, \& A.-M. Pétrequin, Szerk.; pp. 521-599). Presses universitaires de Franche-Comté, Centre de recherche archéologique de la vallée de l'Ain.

Raczky, P., Füzesi, A., Sebők, K., Faragó, N., Csippán, P., \& Anders, A. (2020). A special house from the Late Neolithic tell settlement of Berettyóújfalu-Herpály (Hungary): Reconstruction of a two-storey building, its furnishings and objects from the earlier 5th millennium BC. In S. W. E. Blum, T. Efe, T. L. Kienlin, \& E. Pernicka (Szerk.), From past to present-Studies in memory of Manfred O. Korfmann (pp. 429-457). Habelt.

Rhyzov, S., Stepanchuk, V., \& Sapozhnikov, I. (2005). Raw material provenance in the Palaeolithic of Ukraine: State of problem, current approaches and first results. Archeometriai Mühely, 2(4), 17-25.

Rozoy, J.-G. (1989). The revolution of the bowmen in Europe. In C. Bonsall (Szerk.), The Mesolithic in Europe: Papers presented at the 3. International Symposium Edinburgh 1985 (pp. 13-29). John Donald Publishers.

Šarić, J. (2005). Chipped stone projectiles in the territory of Serbia in Prehistory. Starinar, 55, 9-33.

Siklósi, Zs. (2013). Traces of Social Inequality during the Late Neolithic in the Eastern Carpathian Basin. Eötvös Loránd University, Institute of Archaeological Sciences.

Siklósi, Zs., Faragó, N., Dani, J., Csedreki, L., Kertész, Z., Szikszai, Z., \& Szilágyi, M. (2021). Duality of identity representation in the Copper Age on the Great Hungarian Plain [in press].

Siklósi, Zs., \& Szilágyi, M. (2019). New data on the provenance of copper finds from the Early-Middle Copper Age of the Great Hungarian Plain. Archaeological and Anthropological Sciences, 11(10), 5275-5285. https://doi. org/10.1007/s12520-019-00867-8 
Siklósi, Zs., \& Szilágyi, M. (2021). Culture, period or style? Reconsideration of early and middle Copper age chronology of the Great Hungarian Plain. Radiocarbon, 63(2), 585-646. https:// doi.org/10.1017/RDC.2020.115

Starnini, E., Szakmány, G., Józsa, S., Kasztovszky, Z., Szilágyi, V., Maróti, B., Voytek, B. A., \& Horváth, F. (2015). Lithics from the tell site Hódmezővásárhely-Gorzsa (southeast Hungary): Typology, technology, use and raw material strategies during the Late Neolithic (Tisza culture). In S. Hansen, Raczky Pál, Anders Alexandra, A. Reingruber, Eötvös Loránd Tudományegyetem, \& Deutsches Archäologisches Institut (Szerk.), Neolithic and Copper Age between the Carpathians and the Aegean Sea: Chronologies and Technologies from the 6th to the 4th Millennium BCE; International Workshop Budapest 2012: [Org. By the] Eötvös Loránd University, Institute of Archaeological Sciences [and] Deutsches Archäologisches Institut, Eurasien-Abteilung (pp. 105-128). Habelt.

Starnini, E., Voytek, B. A., \& Horváth, F. (2007). Preliminary results of the multidisciplinary study of the chipped stone assemblage from the Tisza culture site of tell Gorzsa (Hungary). In Janusz Krzysztof Kozłowski \& P. Raczky (Szerk.), The Lengyel, Polgár and related cultures in the Middle/Late Neolithic in Central Europe (pp. 269-278). Polska Akademia Umiejętności.

Szepesi, J., Lukács, R., T. Biró, K., Markó, A., Pécskay, Z., \& Harangi, Sz. (2018). Geology of Tokaj Mountains obsidians. Archeometriai Mühely, 15(3), 167-180.

Szilasi, A. B. (2017). Radiolarite sources from the Bakony mountains: New research. Archaeologia Polona, 55, 243-265.

Szolyák, P., \& Lengyel, Gy. (2014). A Miskolc-Bársony-házi „szakócák” kutatástörténete és techno-tipológiai vizsgálata. A Herman Ottó Múzeum Évkönyve, 53, 11-40.

T. Biró, K. (1998). Lithic Implements and the Circu- lation of Raw Materials in the Great Hungarian Plain During the Late Neolithic Period. Magyar Nemzeti Múzeum.

T. Dobosi, V., \& Kövecses-Varga, E. (1991). Upper Palaeolithic site at Esztergom-Gyurgyalag. An archaeological analysis. Acta Archaeologica Academiae Scientiarum Hungaricae, 43, 233-255.

Tixier, J. (2012). Méthode pour l'étude des outillages lithiques: Notice sur les travaux de J. Tixier $=A$ method for the study of stone tools. Centre National de Recherche Archéologique du Luxembourg.

Whittle, A., Anders, A., Bentley, R. A., Bickle, P., Cramp, L., Domboróczky, L., Fibiger, L., Hamilton, J., Hedges, R. E. M., Kalicz, N., Kovács, Z. E., Marton, T., Oross, K., Pap, I., \& Raczky, P. (2013). Hungary. In P. Bickle \& A. Whittle (Szerk.), The First Farmers of Central Europe: Diversity in LBK Lifeways (pp. 49-100). Oxbow Books.

Zalai-Gaál, I. (2010). Die soziale Differenzierung im Spätneolithikum Südtransdanubiens: Die Funde und Befunde aus den Altgrabungen der Lengyel-Kultur. Archaeolingua. 


\section{A tealevelektöl} a levélhegyekig

TANULMÁNYOK

MESTER ZSOLT TISZTELETÉRE

60. SZÜLETÉSNAPJA ALKALMÁBÓL
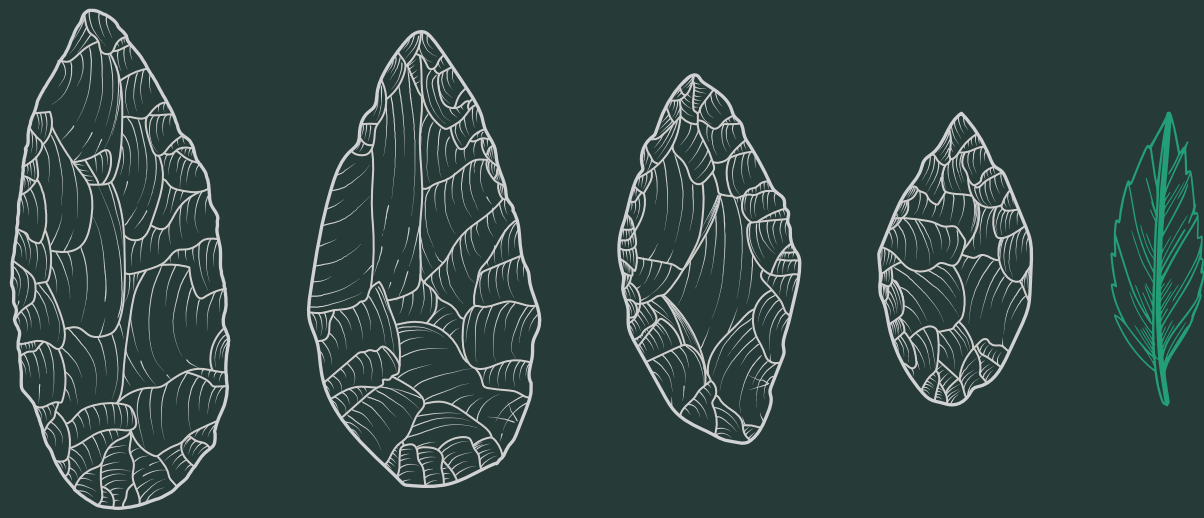

SZERKESZTŐK:

FARAGÓ NORBERT

KIRÁLY ATTILA

SZEGEDI KRISTÓF ISTVÁN 

LITIKUM KÖNYVTÁR 1. 

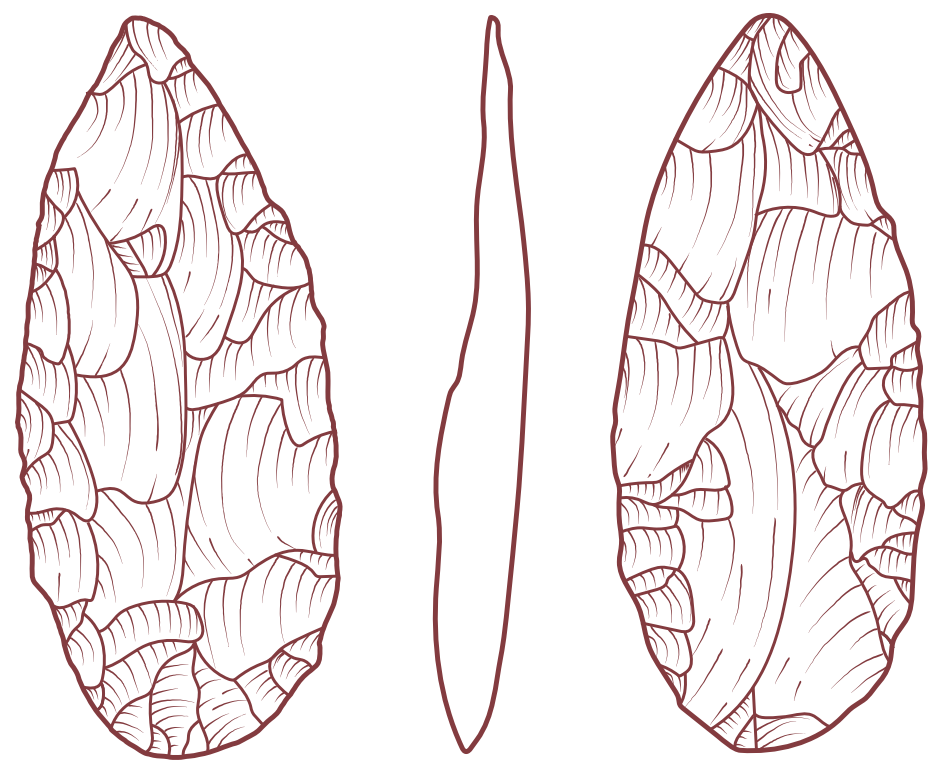

$3 \mathrm{~cm}$

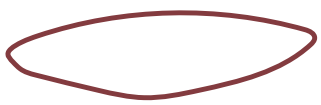

Szeletai levéleszköz

Kozłowski et al., 2009, Planche 11 nyomán. 


\title{
A tealevelektöl a levélhegyekig
}

\author{
TANULMÁNYOK \\ MESTER ZSOLT TISZTELETÉRE \\ 60. SZÜLETÉSNAPJA ALKALMÁBÓL
}

Szerkesztők:

Faragó Norbert

Király Attila

Szegedi Kristóf István
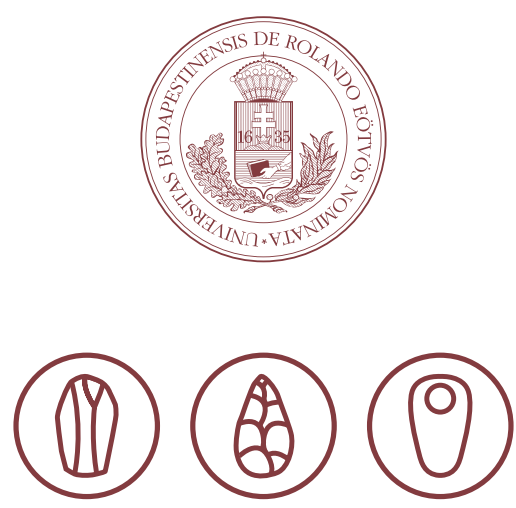

LITIKUM - A KŐKOR KEREKASZTAL FOLYÓIRATA

ELTE BTK RÉGÉSZETTUDOMÁNYI INTÉZET

2021 
A TEALEVELEKTŐL A LEVÉLHEGYEKIG TANULMÁNYOK MESTER ZSOLT TISZTELETÉRE 60. SZÜLETÉSNAPJA ALKALMÁBÓL

LITIKUM KÖNYVTÁR 1.

Kiadó:

Litikum - a Kőkor Kerekasztal Folyóirata

ELTE BTK Régészettudományi Intézet

Felelős kiadó:

Király Attila - szerkesztő, Litikum - a Kőkor Kerekasztal Folyóirata

3524 Miskolc, Jósika M. u. 20.•attila@litikum.hu•https://litikum.hu

Felelős szerkesztők:

FARAGÓ NORBERT, KIRÁLY ATTILA, SZEGEDI KRISTÓF ISTVÁN

Sorozatszerkesztő:

KIRÁLY ATTILA

Grafikai terv, tördelés, borítóterv:

KIRÁLY ATTILA

ISBN (PDF): 978-615-01-1676-1

ISBN (puhafedelű): 978-615-01-1675-4

(C A szerkesztők és a szerzők, 2021 • A kötet a Creative Commons Nevezd meg! - Ne add el! - Így add tovább! 4.0 Nemzetközi Licenc feltételeinek megfelelően használható fel. A mű szabadon használható, terjeszthető és sokszorosítható az eredeti szerző és forrás megjelölése mellett. A feldolgozott, átalakított származékos mű az eredeti licenszfeltételekkel terjeszthető. @(1)@(?

A kötet első nyomása FR4 alakban, tíz nyomtatott példányban készült a Source Sans Pro és Source Serif Pro betűtípusok felhasználásával, melyek az SIL Open Font licensz alá esnek. A kiadvány print-on-demand módon érhető el a felelős kiadótól vagy a Litikum szerkesztőségében.

Nyomta és kötötte: Vareg Nyomda. 


\section{TARTALOMJEGYZÉK}

Köszöntő

VIDA TIVADAR

Mester Zsolt publikációi - bibliográfia 1989-2020

KIRÁLY ATTILA

Társadalmi folyamatok a kőeszköz-kutatásban. A chaîne opératoire koncepció használata újkőkori kőanyagok vizsgálatában

SZILÁGYI KATA

A fosszilis puhatestű vázak szerepének kérdése a magyarországi felső paleolitikumban

BÁLINT CSABA

Demjén-Szőlő-hegy III korai felső paleolit lelőhely

BÉRES SÁNDOR ÉS KEREKES DALMA

Technológiai megfigyelések a rákóczifalvi temető

bifaciális levélhegyén

FARAGÓ NORBERT

Nagykovácsi-Remete-barlang 10. rétegének időrendi kérdései

SZEGEDI KRISTÓF ISTVÁN

Acsa-Rovnya vakaróinak komplex vizsgálata - felszíni

leletegyüttesek a felső paleolitikus tájhasználat

rekonstrukciójában

KIRÁLY ATTILA 